\title{
Investigating Supply-Side Flexibility to Support Sustainability Business Performance: Learning from Coffee Shops in Malang City
}

\author{
Anisa Aprilia*, Fitrotul Laili, Putri Budi Setyowati, Kristoforus Farian Waringga
}

Department of Socio-Economics, Faculty of Agriculture, Universitas Brawijaya, Malang, Indonesia

*Corresponding author. Email: anisa.asa@ub.ac.id

\begin{abstract}
An important dimension of value chain flexibility is supply-side flexibility, which refers to the range and ability to accommodate changes in production output related to internal operating efficiency. Meanwhile, flexibility in supply chain networks can help reduce supply chain risk when dealing with uncertainty. Therefore, supply-side flexibility is crucial in responding to consumer demand to improve business sustainability and competitiveness. This research aims to examine the impact of product efficiency, product complexity, and operational risk on supply-side flexibility (volume). A total of 56 respondents who are coffee shop business owners in Malang city have been used as samples for this research. Of course, the number of samples has been adjusted to the bare minimum of data requirements for research analysis, namely PLS-SEM approach. The findings show that product efficiency and product complexity have a significant direct effect on supply-side flexibility, whereas operation risk has no significant direct effect. Our findings contribute to the literature on supply chain management by filling gaps and assisting managers in making strategic decisions regarding flexibility that support business sustainability.
\end{abstract}

Keywords: Coffee Shops, Operational Risk, Product Complexity, Product Efficiency, Supply Flexibility

\section{INTRODUCTION}

Flexibility in uncertain supply chain networks has been a research challenge in recent years [1]. Indeed, during the current crisis caused by the Covid 19 pandemic, manufacturing and supply chain resilience and flexibility are often explored [2]. In today's increasingly complex business environment, supply chain flexibility has become essential for remaining competitive. Unpredictable supply chain dynamics can be caused by various internal and external factors, such as suppliers, operating systems, customers, and competitors. However, to improve supply chain responsiveness, the company's flexibility plan should be adopted according to the company's business environment by lowering uncertainty and boosting supply chain agility [3]. The flexibility of the supply network in this uncertain climate helps reduce supply chain risks [4].

To gain a competitive edge, firms must improve supply chain management methods to be flexible, sensitive to uncertain conditions, and to cope with changing consumer expectations [5]. Because of the need for flexible supply chain management, it is necessary to plan for alternative prediction scenarios and develop effective response plans [6]. The negative impact of supply chain disruptions can be reduced by developing an investment strategy that examines the balance between responsiveness, risk, and cost and anticipating how much improvement in supply chain flexibility and agility can increase responsiveness to anticipate supply chain disruptions [7].

Businesses will see that flexible supply chains outperform less agile supply chains as they compete with other supply chains in an increasingly uncertain environment. As a result, businesses seeking a competitive advantage are forced to compete at the supply chain and enterprise levels. In practice, the supply chain flexibility dimension can significantly contribute to environmentally friendly operations, and strategically implementing the relevant flexibility can support business sustainability [8]. But when there is no support for flexible supply chains and corporations prioritize alternative forms of flexibility, each supply chain member must apply flexibility with supply chain members at the next level to satisfy needs [9]. 
The coffee shop business makes coffee an icon of the best friend for casual discussions or about business, attracting visitors from all walks of life so that this current business is becoming increasingly popular among coffee businesses and consumers. Furthermore, in a coffee business, supply chain agility has a beneficial impact on performance. As a result of supply chain agility, coffee shops can sustain and grow consumer satisfaction and loyalty [10]. Meanwhile, rising customer expectations for product variety, shorter product lifecycles, and unpredictable demand are driving the need for supply chain flexibility in the face of fierce competition and changing circumstances [11]. The level of flexibility and complexity of the supply chain network can be used to estimate efforts to improve supply chain resilience. This research contributes to the linkage of product efficiency and complexity, as well as operational risk, to supply flexibility in areas where studies in the field of agribusiness, particularly the coffee shop business, have not been widely explored. Mix flexibility refers to the range and ability to alter items currently being produced, whereas volume flexibility refers to the range and ability to modify production output [12]. These issues highlight the importance of conducting empirical research into the paths that coffee shops can take to achieve a supply of business-supporting flexibility. In this study, the following research questions are addressed: First, how does product efficiency affect supply-side flexibility from the perspective of a business actor? Second, how does the complexity of a product affect supply-side flexibility? Third, what effect does operational risk have on supply-side flexibility? This study adds to theory and practice by examining industry and specific themes, namely supply chain flexibility, while accounting for the effects of product efficiency, product complexity, and operational risks.

\section{RESEARCH METHODS}

Respondents were coffee shop owners, with the majority of the businesses being privately owned and this study was carried out during the Covid 19 pandemic. The number of respondents that met the minimum sample size standard for the PLS-SEM (Partial Least Squares - Structural Equation Modeling) analysis used in this study is 56, even exceeding the suggested sample size. This sample size exceeds the minimum sample size based on the rule of ten times the number of constructs in research, which has become popular due to its ease of use [13]. Furthermore, this sample size exceeded the minimum sample size requirements based on statistical power of $80 \%$ with a maximum number of arrows pointing at a construct of 3 and a minimum $\mathrm{R}$ squares value of 0.50 for $\mathrm{a}$ significance level of $1 \%$ [14]. Meanwhile, PLS-SEM is used to examine the overall research framework, beginning with testing measurement models and structural models. PLS-SEM was chosen because it has been shown to effectively test measurement models as well as structural models at the same time [15]. PLSSEM is used to test the effect of product efficiency, complexity, and risk operation on supply flexibility. PLS regression could be used to relate responses $\mathrm{Y}$ to predictors X, and PLS-SEM is appropriate if the study's purpose is to forecast important target constructs or identify key driver constructs [14,16]. Furthermore, Table 1 shows the constructs and measures used in the study, which are scored on a Likert scale of 1 to 7 (strongly disagree to agree strongly).

\section{RESULTS AND DISCUSSION}

Relationships formed as a result of hypotheses must be tested. However, before testing the hypothesis, it is necessary to assess the instrument's reliability for each indicator and the validity of the model used in this study.

The first validity test involves determining convergent validity. If the convergent validity test yields a value greater than 0.3 , it meets the standard [14]. The next type of validity is discriminant validity, which is determined by calculating the Square Root of the Average Variance Extracted (AVE) value. As a condition for discriminant validity, the obtained AVE value must be greater than 0.5 . This means that $50 \%$ more variance than the indicator used can be adequately explained [14]. The reliability test follows, which is based on Cronbach's Alpha and Composite Reliability values. More than 0.6 for the Cronbach's Alpha value and more than 0.7 for the Composite Reliability test are required in the test [18].

Based on the data in Table 2, it is clear that this study passed the convergent validity test, as the factor loading values of all indicators are greater than 0.3 . The OR1 indicator has the smallest value of 0.709 and the SSF1 indicator has the highest value of 0.953 . Furthermore, it can be seen in Table 3 that this study passed the discriminant validity test by examining the value of the Square Root of Average Variance Extracted (AVE), where the square root of the AVE for each latent construction has a correlation value that is greater than the correlation of other latent constructs. The overall value of the square root of AVE is also greater than 0.5, indicating that there is no discriminant validity problem in the measurement model used in this study.

The results of the reliability test are described in the following stage, which is shown in Table 4. Based on the data in the table, it is clear that this study passed the reliability test, with all latent constructs in this study having a Composite Reliability value of greater than 0.7 and a Cronbach Alpha value of greater than 0.6. Furthermore, based on the validation test results, it is clear that the measurement model in this study met all of the reliability and validity criteria. 
Table 1. Measurement of constructs

\begin{tabular}{|l|l|}
\hline \multicolumn{1}{|c|}{ Construct } & \multicolumn{1}{c|}{ Measures } \\
\hline Product Efficiency (PF) & Firm has the ability to quickly change its product mix. \\
\cline { 2 - 3 } & Firm is capable of producing a wide range of products. \\
\cline { 2 - 3 } Product complexity (PC) & Firm has the ability to transition from one type of product to another. \\
\cline { 2 - 2 } Operation risk (OR) & Provide customers with a diverse range of product bundling options. \\
\cline { 2 - 3 } & Firm sells a product that is made up of many different components. \\
\hline & Firm frequently introduces new product variants within an existing product line. \\
\cline { 2 - 3 } Supply side flexibility (SSF) & $\begin{array}{l}\text { Firm frequently suffers from logistical failures that have an impact on product } \\
\text { inventory. }\end{array}$ \\
\cline { 2 - 3 } & $\begin{array}{l}\text { Firm suffers from frequent supply failures, which have an impact on coffee shop } \\
\text { operations. }\end{array}$ \\
\cline { 2 - 3 } & $\begin{array}{l}\text { Firm is capable of producing a wide range of products. } \\
\text { Firm has the ability to transition from one type of product to another (scope of } \\
\text { operation flexibility) }\end{array}$ \\
\cline { 2 - 2 } & $\begin{array}{l}\text { Firm can operate at a variety of output levels (adaptability of operation } \\
\text { flexibility) }\end{array}$ \\
\cline { 2 - 2 } & $\begin{array}{l}\text { Changes in volume allocation among existing clients occur on a regular basis } \\
\text { (logistics flexibility) }\end{array}$ \\
\hline
\end{tabular}

Sources: $[15,17]$

Table 2. Convergent validity

\begin{tabular}{|c|c|}
\hline Variable & Loading Factors Value \\
\hline PE1 & 0.863 \\
\hline PE2 & 0.902 \\
\hline PE3 & 0.833 \\
\hline PC1 & 0.830 \\
\hline PC2 & 0.915 \\
\hline PC3 & 0.814 \\
\hline OR1 & 0.709 \\
\hline OR2 & 0.908 \\
\hline OR3 & 0.917 \\
\hline OR4 & 0.829 \\
\hline SSF1 & 0.953 \\
\hline SSF2 & 0.941 \\
\hline SSF3 & 0.940 \\
\hline
\end{tabular}

Table 3. Discriminant validity

\begin{tabular}{|l|l|l|l|l|}
\hline Construct & \multicolumn{1}{|c|}{ PE } & \multicolumn{1}{c|}{ PC } & \multicolumn{1}{c|}{ OR } & \multicolumn{1}{c|}{ SSF } \\
\hline PE & $(0.867)$ & 0.629 & 0.240 & 0.605 \\
\hline PC & 0.629 & $(0.854)$ & 0.308 & 0.634 \\
\hline OR & 0.240 & 0.308 & $(0.845)$ & 0.275 \\
\hline SSF & 0.605 & 0.634 & 0.275 & $(0.945)$ \\
\hline
\end{tabular}

Table 4. Reliability test

\begin{tabular}{|c|c|c|}
\hline Construct & $\begin{array}{c}\text { Composite } \\
\text { Reliability }\end{array}$ & $\begin{array}{c}\text { Cronbach's } \\
\text { Alpha }\end{array}$ \\
\hline PE & 0.900 & 0.834 \\
\hline PC & 0.890 & 0.813 \\
\hline OR & 0.908 & 0.863 \\
\hline SSF & 0.961 & 0.904 \\
\hline
\end{tabular}

The first measurement is collinearity testing, which is done by examining the value of the variance inflation factor (VIF). Because the VIF value has a tolerance limit of 5 , the results must be less than 5 [19].
According to the results in Table 5, the PE, PC, OR, and SSF variables have values of 1.876, 2.036, 1.119, and 1.911, respectively. As a result, it is possible to conclude that collinearity is not a problem. Furthermore, measurements were taken to test the construction's explanatory strength by looking at the value of $\mathrm{R}^{2}$. According to the results in Table 6, the supply side flexibility (SSF) variable has an $\mathrm{R}^{2}$ value of 0.508 . This demonstrates that the explanatory power of the construction in this model is adequate for exogenous variables.

The next step is to test Q2 to see how predictive the endogenous variables in the structural model are. According to the data in Table 6, the Q2 value for the supply side flexibility (SSF) variable is 0.516 . This demonstrates that the predictive relevance of endogenous constructions on the structural model is high.

The next test is used to determine the magnitude of the effect or contribution of exogenous variables on endogenous variables [14]. Accordingly, the effect size value is classified as small, medium, or large, with values of $0.02,0.15$, and 0.35 , respectively. The contribution values of the $\mathrm{PE}, \mathrm{PC}, \mathrm{OR}$ variables are $0.199,0.248$, and 0.061 , respectively, as shown in Table 7. As a result, the PE and $\mathrm{PC}$ variables have a moderate effect, while the OR variable has a minor effect.

Table 5. VIF

\begin{tabular}{|c|c|c|c|c|}
\hline & PE & PC & OR & SSF \\
\hline VIF & 1.876 & 2.036 & 1.119 & 1.911 \\
\hline
\end{tabular}

Table 6. R-Squared $\left(\mathrm{R}^{2}\right)$ and $\mathrm{Q}-$ Squared $\left(\mathrm{Q}^{2}\right)$

\begin{tabular}{|c|c|}
\hline & SSF \\
\hline $\mathrm{R}^{2}$ & 0.508 \\
\hline $\mathrm{Q}^{2}$ & 0.516 \\
\hline
\end{tabular}


Table 7. Effect Size

\begin{tabular}{|c|c|c|c|}
\hline & PE & PC & OR \\
\hline $\begin{array}{c}\text { Effect } \\
\text { Size }\end{array}$ & 0.199 & 0.248 & 0.061 \\
\hline
\end{tabular}

The path coefficient diagram shows that the path coefficients on all three constructs have a positive influence. This is demonstrated by the relationship between each variable that has a significant effect on the path coefficient values on the PE, PC, and OR variables, which are $0.31,0.37$, and 0.14 , respectively.

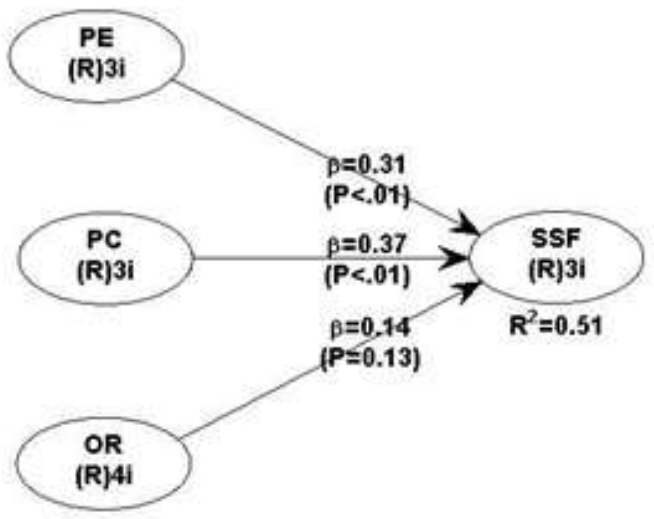

Figure 1 The result of research model

GoF is used because it has been shown to be a useful tool for assessing the level of model fit in PLS-SEM [20]. Meanwhile, the p-value, which must be less than 0.05 , determines the value limit allowed as a condition for the value of APC, ARS, and AARS. According to the results, the values of APC, ARS, and AARS all obtained results of 0.273 ( $\mathrm{p}=0.007), 0.508$ ( $\mathrm{p}<0.001)$, and $0.479(\mathrm{p}<0.001)$, respectively, indicating that it is in a good category. Furthermore, AVIF and AFVIF are ideal if their value is less than 3.3 and can still be accepted or tolerated if their value is greater than 5 [18]. According to the results, the AVIF and AFVIF values are 2.205 and 1.735 , respectively, indicating that they are in ideal condition.

Tenenhaus GoF (GoF) has three desired value limits, namely a small category if the gof value is 0.1 , a medium category if the GoF value is 0.25 , and a large category if the GoF value is 0.36 . The value of tenenhaus $\mathrm{GoF}(\mathrm{GoF})$ is 0.626 and falls into the large category, implying that the model's predictive power in this study is strong. In addition, the resulting values for the measurement of model fit are $\mathrm{SPR}=1, \mathrm{RSCR}=1$, $\mathrm{SSR}=1$, and NLBCDR $=1$, with the limit of the ideal value being 1 , implying that the four measurements of model fit are met. The inner model is acceptable based on the results of the ten goodness of fit model measurements.

The WarpPLS v7.0 software application was used to test hypotheses. The hypothesis testing decision rule is followed if the P-Value is $0.10,0.05$, or 0.01 and 0.01 is highly significant (Solimun et al., 2017). According to the path coefficient test and P-Value in Table 8 and Figure 1, the PE, PC, and OR variables all positively influence the SSF variable, with path coefficient values of $0.305,3.07$, and 0.145 , respectively. With a P-Value of 0.007 , the effect of PE on SSF falls into the weakly significant category and accepts H0. With a P-Value of 0.001 , the effect of PC on SSF falls into the highly significant category and accepts $\mathrm{H} 1$. While the effect of OR on SSF has a P-Value of 0.129 , it is classified as insignificant and accepts $\mathrm{H} 0$.

This study's findings show that Product Complexity (PC) is the primary direct driver of supply flexibility. This is demonstrated by the path coefficient test results, which show that PC has a high significance level. Product complexity is a high-level ability of the company to adapt to changing market conditions and the ability to adjust its operating activities [15]. As a result, if the coffee shop business has a high level of product complexity, the company can offer different products more flexibly in response to market conditions and desires. On the other hand, if the company lacks product complexity, it will impede internal processes because the company will be unable to achieve the desired business results. However, creating product complexity necessitates excellent coordination between suppliers and the company, both during procurement and in creating products that are unique to consumers [21].

Product complexity can also increase company productivity [22]. As a result, if coffee shops in Malang City can increase product complexity, the company's productivity can be increased to support business continuity. However, it should be noted that the degree to which the diversity and quality of the raw materials and technology used influence the product's complexity [23]. Product complexity is also related to how coffee shops develop new innovations and educate customers. Suppliers' creativity is also required and must be communicated to supply chain parties as a strategy and knowledge of co-creation. If the coffee shop can accomplish this, it will increase the supply side's flexibility. However, before introducing the product to consumers, market research must be conducted to ensure that there is no market failure [24].

Table 8. Hypothesis testing

\begin{tabular}{|c|c|c|c|}
\hline Relationship between variables & Path Coefficient & P-value & Description \\
\hline PE -> SSF & 0.305 & 0.007 & Significantly weak \\
\hline PC -> SSF & 0.307 & 0.001 & Significantly strong \\
\hline OR -> SSF & 0.145 & 0.129 & Not significant \\
\hline
\end{tabular}


On the relationship between product efficiency and supply side flexibility, different results were obtained, with the results indicating a positive effect but at a low level of significance. Product efficiency is a component of the value concept of customer value based on efficiency [25]. Customer value is used to determine how products perform and for businesses to determine a competitive market structure. The insignificant SSF results indicate that coffee shops have been unable to increase customer value through the products they offer. Reliability, safety, and ease of use are all aspects of customer value in coffee products that must be considered [26].

Moreover, coffee shop businesses should provide the highest level of customer value to the market's product options. Therefore, the coffee shop business can be said to have achieved product efficiency if it is able to provide maximum customer value. Furthermore, a value creation strategy is required, which indicates the company's approach to varying inputs and outputs. The value creation strategy is implemented to improve product performance to create offering flexibility by providing maximum customer value.

Meanwhile, the relationship between operational risk variables and supply side flexibility was found to be insignificant. The researcher discovered that this relationship was insignificant because businesses frequently failed to anticipate operational risk. This is consistent with the findings other research found that companies frequently face operational risks that are not properly anticipated, causing them to disrupt goal achievement and ultimately result in high-quality costs [27]. As a result, the coffee shop should implement operational risk management (ORM). Because the company is able to deliver a wide range of quality products while increasing customer value, the implementation of a complex ORM in every part of the supply chain and within the company will have an impact on reducing operational risk and increasing supply-side flexibility. This will also impact the company in terms of increasing operational efficiency to achieve company goals [28].

Controlling operational risk has a significant positive impact on profitability [29]. As a result, coffee shop owners in Malang City must pay closer attention to operational risks. Stability and increased profits due to operational risk control can be indicators that coffee shop businesses can achieve long-term business success. However, one of the operational risk problems that receive less attention is outsourcing and its complexity, which can lead to new risks within the company if the company multi-sources [30]. Therefore, coffee shop should consider which party is best suited to collaborate in the supply of raw materials to avoid additional risks.

\section{CONCLUSION}

According to the study's findings, the three variables have a positive impact on increasing supply-side flexibility. As a result, coffee shop owners and managers must consider these three factors in order to maintain and improve their business performance. Meanwhile, product complexity is the primary driver of increased supply-side flexibility. Product complexity translates into a company's ability to deal with environmental changes and adapt its operations. As a result, product complexity has a large impact on supplyside flexibility. Companies that can achieve product complexity can offer a diverse range of products to market consumers. However, in order to avoid significantly increasing production costs, raw material resources and technology should be considered. Moreover, because businesses frequently ignore operational risks, operational risk has a negligible effect on supply side flexibility in this study. Operational risk must be managed in order for the coffee shop business to provide a high level of customer value. Controlling operational risk, on the other hand, can increase the company's profitability, which can be an indication that the company has achieved stable business performance.

\section{AUTHORS' CONTRIBUTIONS}

Following are the authors' contributions to the article: study conception and design: Anisa Aprilia; collected the data: Fitrotul Laili, Putri Budi Setyowati; contributed data or analysis tools: Anisa Aprilia, Fitrotul Laili; Putri. Budi Setyowati; performed the analysis: Anisa Aprilia; wrote the paper: Anisa Aprilia; Kristoforus Farian Waringga. Authors all agreed on final version of manuscript after reviewing and approving on the results.

\section{ACKNOWLEDGMENTS}

We would like to thank the Institution of Research and Community Services of Universitas Brawijaya (LPPMUB) for providing research funding help and support and the owners and employees of coffee shop businesses in Malang City provided information for research data used in writing this article.

\section{REFERENCES}

[1] Chatzikontidou A, Longinidis P, Tsiakis P, Georgiadis MC. Flexible supply chain network design under uncertainty. Chemical Engineering Research and Design [Internet]. Elsevier BV; 2017 Dec;128:290-305. Available from: http://dx.doi.org/10.1016/j.cherd.2017.10.013

[2] R. R. Flexible business strategies to enhance resilience in manufacturing supply chains: An empirical study. Journal of Manufacturing 
Systems [Internet]. Elsevier BV; 2020 Nov; Available from: http://dx.doi.org/10.1016/j.jmsy.2020.10.010

[3] Yi CY, Ngai EWT, Moon K. Supply chain flexibility in an uncertain environment: exploratory findings from five case studies. Supply Chain Management: An International Journal [Internet]. Emerald; 2011 Jun 21;16(4):271-83. Available from: http://dx.doi.org/10.1108/13598541111139080

[4] Sreedevi R, Saranga H. Uncertainty and supply chain risk: The moderating role of supply chain flexibility in risk mitigation. International Journal of Production Economics [Internet]. Elsevier BV; 2017 Nov;193:332-42. Available from:

http://dx.doi.org/10.1016/j.ijpe.2017.07.024

[5] Jangga R, Ali NM, Ismail M, Sahari N. Effect of environmental uncertainty and supply chain flexibility towards supply chain innovation: an exploratory study. Procedia Economics and Finance [Internet]. Elsevier BV; 2015;31:262-8. Available from: http://dx.doi.org/10.1016/s22125671(15)01228-9

[6] Onkal D, Aktas E. Supply Chain Flexibility: Managerial Implications. Supply Chain Management - Pathways for Research and Practice [Internet]. InTech; 2011 Aug 1; Available from: http://dx.doi.org/10.5772/21014

[7] Shekarian M, Reza Nooraie SV, Parast MM. An examination of the impact of flexibility and agility on mitigating supply chain disruptions. International Journal of Production Economics [Internet]. Elsevier BV; 2020 Feb;220:107438. Available from: http://dx.doi.org/10.1016/j.ijpe.2019.07.011

[8] Liu Yang, Zhang Yufeng, Batista Luciano, Rong Ke. Green operations: What's the role of supply chain flexibility? International Journal of Production Economics [Internet]. Elsevier BV; 2019 Aug; Available from: http://dx.doi.org/10.1016/j.ijpe.2019.03.026

[9] Manders JHM, Caniëls MCJ, Ghijsen PWT. Exploring supply chain flexibility in a FMCG food supply chain. Journal of Purchasing and Supply Management [Internet]. Elsevier BV; 2016 Sep;22(3):181-95. Available from: http://dx.doi.org/10.1016/j.pursup.2016.06.001

[10] Aprilia A, Laili F, Setyowati PB, Febriana RA, Waringga KF, Waringga F. Pengaruh ketangkasan rantai pasok terhadap kinerja bisnis kedai kopi di Kota Malang. JSEP (Journal of Social and Agricultural Economics) [Internet]. UPT Penerbitan Universitas Jember; 2021 Mar 30;14(1):32. Available from: http://dx.doi.org/10.19184/jsep.v14i1.20547 [In Indonesian]

[11] Fischer J-H, Thomé AMT, Scavarda LF, Hellingrath B, Martins R. Development and application of a maturity measurement framework for supply chain flexibility. Procedia CIRP [Internet]. Elsevier BV; 2016;41:514-9. Available from: http://dx.doi.org/10.1016/j.procir.2015.12.107

[12] Gosling J, Purvis L, Naim MM. Supply chain flexibility as a determinant of supplier selection. International Journal of Production Economics [Internet]. Elsevier BV; 2010 Nov;128(1):11-21. Available from: http://dx.doi.org/10.1016/j.ijpe.2009.08.029

[13] Kock N, Hadaya P. Minimum sample size estimation in PLS-SEM: The inverse square root and gamma-exponential methods. Information Systems Journal [Internet]. Wiley; 2016 Nov 29;28(1):227-61. Available from: http://dx.doi.org/10.1111/isj.12131

[14] Hair, J F, Hult G. T. M., Ringle C. M., \& Sarstedt M. A Primer on Partial Least Squares Structural Equation Modeling (PLS-SEM). In SAGE Publications (1st ed.); (2014).

[15] Irfan M, Wang M, Akhtar N. Enabling supply chain agility through process integration and supply flexibility. Asia Pacific Journal of Marketing and Logistics [Internet]. Emerald; 2019 Oct 25;32(2):519-47. Available from: http://dx.doi.org/10.1108/apjml-03-2019-0122

[16] Tenenhaus M, Mauger E, Guinot C. Use of ULSSEM and PLS-SEM to Measure a Group Effect in a Regression Model Relating Two Blocks of Binary Variables. Handbook of Partial Least Squares [Internet]. Springer Berlin Heidelberg; 2009 Nov 16;125-40. Available from: http://dx.doi.org/10.1007/978-3-540-32827-8_6

[17] Quanxi L, Yibing Q, Wanche Z. Research on Measurement and Evolutionary Mechanisms of Supply Chain Flexibility. Supply Chain Management - Applications and Simulations [Internet]. InTech; 2011 Sep 12; Available from: http://dx.doi.org/10.5772/19204

[18] Solimun M., Fernandes A. A. R. \& Nurjannah. Metode Statistika Multivariat. UB Press; 2017. [In Indonesian] 
[19] Kock N. Common Method Bias: A Full Collinearity Assessment Method for PLS-SEM. Partial Least Squares Path Modeling [Internet]. Springer International Publishing; 2017;245-57. Available from: http://dx.doi.org/10.1007/978-3319-64069-3_11

[20] Henseler J. Guest editorial. Industrial Management \& Data Systems [Internet]. Emerald; 2016 Oct 17;116(9):1842-8. Available from: http://dx.doi.org/10.1108/imds-09-20160366

[21] Eckstein D, Goellner M, Blome C, Henke M. The performance impact of supply chain agility and supply chain adaptability: the moderating effect of product complexity. International Journal of Production Research [Internet]. Informa UK Limited; 2014 Oct 27;53(10):302846. Available from: http://dx.doi.org/10.1080/00207543.2014.970707

[22] Oktaviani (Universitas Indonesia) S, Djamaluddin (Universitas Indonesia) $\mathrm{S}$. Pengaruh impor bahan baku dan kompleksitas produk terhadap produktivitas perusahaan. Jurnal Manajemen Industri dan Logistik [Internet]. Politeknik APP Jakarta; 2020 Feb 6;4(1):10-26. Available from: http://dx.doi.org/10.30988/jmil.v4i1.284 [In Indonesian]

[23] Mubarok MH. Kompleksitas model bisnis adaptif berbasis teknologi digital dan jaringan bisnis internasional. Malia: Journal of Islamic Banking and Finance [Internet]. State Islamic College of Kudus; 2018 Nov 6;1(1). Available from: http://dx.doi.org/10.21043/malia.v1i1.3984 [In Indonesian]

[24] Wang, Y., Wu, J., Zhang, R., Shafiee, S., \& Li, C. (2020). A "user-knowledge-product" Cocreation cyberspace model for product innovation. Complexity, 2020(1), 1-20. https://doi.org/10.1155/2020/7190169

[25] Bauer H. H., Hammerschmidt $M$ \& Staat $M$. Analyzing product efficiency - a customeroriented approach. Institute for Market-Oriented Management; 2004: 57(1), 1-31.

[26] Suprianto, Sarifudin. Analisis Efisiensi Dan Nilai Tambah Produk Agroindustri Olahan Kerupuk Kulit Sapi (Studi Kasus Di Seganteng Kota Mataram). Journal of Economics and Business [Internet]. Universitas Mataram; 2020 Nov 14;6(2):114-33. Available from: http://dx.doi.org/10.29303/ekonobis.v6i2.51 [In Indonesian]
[27] Soegiharto M. V, Sugiarti, Y. Penerapan operational risk management untuk meningkatkan efisiensi quality cost pada PT. SLC. Jurnal Ilmiah Mahasiswa Universitas Surabaya; 2012: 1(1), 1-19 [In Indonesian]

[28] Radomska J. Operational risk associated with the strategy implementation. Management [Internet] Walter de Gruyter GmbH; 2014 Dec 1;18(2):3143. Available from: http://dx.doi.org/10.2478/manment-2014-0040

[29] Safei DM. Pengaruh risiko pembiayaan dan risiko operasional terhadap profitabilitas di Bank BJB Syariah kantor cabang Tasikmalaya. Inklusif (Jurnal Pengkajian Penelitian Ekonomi Dan Hukum Islam) [Internet]. IAIN Syekh Nurjati Cirebon; 2020 Jun 24;5(1):35. Available from: http://dx.doi.org/10.24235/inklusif.v5i2.5264. [In Indonesian]

[30] Bott J, Milkau U. Outsourcing risk: a separate operational risk category? The Journal of Operational Risk [Internet]. Infopro Digital Services Ltd; 2015 Sep;10(3):109-37. Available from: http://dx.doi.org/10.21314/jop.2015.152 